\title{
AS IMAGENS E AS LEIS: DIÁLOGOS ENTRE DISCURSOS NORMATIVOS E ICONOGRÁFICOS MEDIEVAIS NO DECRETUM DE GRACIANO
}

\section{The images and the laws: dialogues between medieval normative and iconographic discourses in the Gratian's Decretum}

\author{
Prof. Dr. Guilherme Antunes Júnior \\ Doutor em História pelo PPGHC/UFRJ - Programa de Pós-Graduação em História da \\ Universidade Federal do Rio de Janeiro \\ guiantunesjr@yahoo.com.br \\ ORCID: https://orcid.org/0000-0003-4001-8080
}

\begin{abstract}
Resumo :
O presente trabalho visa a analisar duas miniaturas contidas no Decretum de Graciano, reunião de textos normativos compilados no século XI. Sabe-se que o manuscrito de Graciano contém variado material que abrange textos jurídicos, cânones conciliares, epístolas, textos da Patrística, trechos da Bíblia, literatura normativa secular e mais. Para analisar as imagens medievais, faço uso da categoria gênero como ferramenta conceitual histórica.

Palavras-chave: Decretum de Graciano - iconografia - gênero

Abstract:

This paper targets to analyze two miniatures contained in the Gratian's Decretum, an aggregate of normative texts compiled in the 11th century. Gratian's manuscript is known to contain a variety of material covering legal texts, conciliar canons, epistles, Patristic texts, Bible passages, secular normative literature, and more. To analyze medieval images, I use the category gender as a historical conceptual tool.
\end{abstract}

Key-works: Gratian's Decretum - iconography - gender study 


\section{Introdução}

O presente artigo objetiva analisar duas miniaturas de dois manuscritos do chamado Concordia Discordantium Canoum, também conhecido como Decretum de Graciano. Datado do século XII, o livro é uma compilação de variados textos de caráter normativo religioso e secular, bem como trechos bíblicos, patrísticos, narrativos, canônicos, etc. As miniaturas são uma capitular $Q$, o manuscrito w.133, e uma história sequenciada, o 262. Ambos são exemplares relacionados à Causa 33, um litígio que envolve uma relação matrimonial contestada pelo fato de o homem ser considerado impotente sexualmente e, portanto, imprestável ao casamento. A esposa pede a anulação do contrato marital.

Minha análise das fontes parte de considerações epistemológicas a respeito do gênero. As relações de gênero são, antes de tudo, relações de poder. Joan Scott define gênero a partir de duas proposições que se conectam e são interdependentes: “... (1) o gênero é um elemento constitutivo de relações sociais baseadas nas diferenças percebidas entre os sexos e (2) e gênero é uma forma primária de dar significado às relações de poder (SCOTT, 1995, p. 86)." Visto isso, entendo que as miniaturas, em conjunto com o texto decretal, constroem discursos acerca dos papeis sociais em contexto marital, atribuindo ao homem e à mulher funções hierárquicas e desiguais. A esposa busca, portanto, mecanismo de escape das imposições matrimoniais, enquanto o marido tenta restituir a normalidade exigindo a reparação esponsal.

Este trabalho está dividido em etapas. Primeiro, exponho as especificidades documentais do Decretum, considerando a auctoritas, a composição e a datação da fonte. Em seguida, analiso separadamente as miniaturas, abordando os elementos constitutivos das imagens. Por fim, proponho algumas reflexões sobre gênero, texto normativo e iconografia medieval.

\section{O Decretum de Graciano}

O livro Concordia Discordantium Canoum, conhecido como Decretum, escrito por Graciano foi, provavelmente, finalizado depois do Segundo Concílio de Latrão, 
após o ano de 1139. Não sabemos quase nada sobre o autor. Especula-se que foi um monge, advogado e, possivelmente, professor em Bolonha. A obra de maneira geral está dividida em três partes. Na primeira, estão divididas cento e uma Distinctiones, que são as fontes da lei, a hierarquia eclesiástica e a disciplina dos clérigos. A segunda é chamada de Cause, sendo trinta e seis temáticas divididas em Questiones, que abordam assuntos diversos como matrimônio, simonia, processos judiciais, ordens religiosas, heresias etc. A terceira parte é constituída de cinco Distinctiones, e trata dos sacramentos da Igreja (WINROTH, 2000, p. 5).

Sobre as etapas de produção, divulgação, metodologia e circulação dos manuscritos, há discussões ricas e, ao mesmo tempo, aparentemente, intermináveis. Não é minha matéria discutir as questões específicas sobre a cronologia e a autoria da Concordia, pois isso foge às intenções deste artigo. Graciano teria sido, em parte, responsável pela redação completa do Decretum, considerando que o texto surgira no ano de 1139, e, em seguida, o que se tinha como documentação eram cópias do ano de 1151. ${ }^{1}$ No entanto, a data de redação foi amplamente revista ao longo de pelo menos 60 ou 70 anos do século passado. No oitavo centenário comemorativo da obra, ocorrido em Toledo em 1952, já se admitia que o texto poderia ser de idade anterior (MIRANDA VICENTE, 1952, p. 391). Por conseguinte, acreditava-se que as fontes disponíveis foram produzidas por volta de 1251, mas, com novas investigações que ocorreram na segunda metade do século XX, percebeu-se que pelo menos quatro documentos, na verdade, eram "primários", isto é, decorrentes do ano de 1139, ou mesmo antes (WINROTH, 2004, p. 5). A razão pela qual se acredita que Graciano produziu o Decretum em torno dos anos de 1140 é a citação, segundo Winroth, a respeito de um decreto do Segundo Concílio de Latrão de 1139, presidido pelo papa Inocêncio II, bispo de Roma de 1130 a 1143, pois há uma referência explícita ao cânone conciliar 28 (WINROTH, 2000, p. 137). A partir daí, discutiu-se se essa citação do segundo lateralense não seria uma interpolação, isto é, um acréscimo a posteriori de apenas um trecho específico do cânone 28 (PENNINGTON, 2014, p. 682).

Em relação à autoria do Decretum, as discussões são também amplamente extensas. Sabe-se que o texto de Graciano foi escrito em etapas, e “... no había sido escrita en un único y grandioso momento creativo, porque la versión original pasó por sucesivas etapas de redacción" (VIEJO-XIMÉNEZIUS, 2005, p. 433). Essa hipótese é 
corroborada pelo fato de o Decretum ser, além de um documento extenso e complexo, uma compilação de textos de diferentes origens e gêneros. São decretais papais, textos bíblicos, cânones conciliares, fragmentos de escritos dos Pais da Igreja e peças de legislações seculares (WINROTH, 2000, p. 5). Isso sugeriria que Graciano teria ao seu alcance uma biblioteca surpreendente para reunir tal soma de materiais tão diferentes (BRUNDAGE, 1987, p. 230). Essa hipótese foi posta à prova, pois há indícios relevantes de que Graciano teria, na verdade, revisado seus textos, e acrescentado novos em seguida, trabalhando sempre por etapas. E ainda há quem defenda que o monge de Bolonha teve o auxílio de outros profissionais para compilação e redação do Decretum. Mesmo essa suposição é vista com desconfiança, uma vez que há nos manuscritos, considerados originários, elementos linguísticos, textuais e discursivos provenientes de uma única pessoa (PENNINGTON, 2014, p. 681).

De qualquer forma, não irei trabalhar com os textos que formaram o Decretum da primeira metade do século XII. Minha proposta é analisar duas peças de iconografia de cópias miniadas posteriores. Uma delas pertence a um manuscrito do fím do século XIII, o w.133, mais especificamente o fólio 277r, datado entre 1280 e 1290, e depositado no Walters Art Museum, em Baltimore, Estados Unidos. Provavelmente pertenceu à abadia cisterciense de Hainaut, atual Bélgica. $\mathrm{O}$ manuscrito foi produzido a partir de uma cópia do Decretum feita por Bartolomeu de Brescia, possivelmente em meados do século XIII, acrescida de outras glosas nas margens feitas por Johannes Teutonicus. O outro manuscrito está no Fitzwilliam Museum, em Cambridge, Inglaterra. O ms 262, fólio 86v, está datado entre 1300 e 1330. Trata-se de uma miniatura historiada, isto é, sequenciada, em quatro quadrinhos. ${ }^{2}$ A fonte impressa do Decretum de Graciano que uso foi editada e revisada por O. P. Augustine Thompson, em 1994, a partir da publicação e tradução de John T. Noonan Jr, em 1967, pela Universidade da Califórnia.

Tanto o ms w.133 quanto o ms. 262 tratam da chamada causa 33, cujo conteúdo são comentários narrados por Graciano a respeito da impotência sexual de um marido, levantando questões teológicas e jurídicas que envolviam tal decisão. A carta recebida por Graciano detalha a seguinte situação: um homem foi enfeitiçado (Si per sortiarias) e é impedido te ter relações sexuais com sua esposa. A esposa, então, se casa publicamente com seu amante. O primeiro marido recupera sua virilidade e reivindica 
sua esposa. Entretanto, após o restabelecimento marital, o marido decide se entregar ao celibato, sem o consentimento da mulher. A partir dessa complexa situação, Graciano responde a cinco questionamentos a fim de desemaranhar esse caso. Primeiro, pode um marido deixar sua esposa por impotência? Segundo, diante da impotência do marido, a esposa pode se casar com seu amante, tendo ela fornicado secretamente? Terceiro, pode um crime ser perdoado através da confissão somente no coração, ou seja, sem a remissão de um clérigo? Quarto, poderia um homem "pagar a dívida" (recuperar a virilidade) com sua esposa apenas com orações? E, finalmente, poderia um marido adotar o celibato sem o consentimento de sua esposa, ou poderia ele conseguir a permissão da esposa por meio da violência e do medo? Graciano dedica um considerável espaço para as respostas, tornando a Causa 33 a maior do Concordia cujo conteúdo trata de matrimônio.

Nosso objetivo é comparar as imagens e analisar como os discursos são construídos a partir do diálogo, sempre tenso e dialético, entre texto e imagens.

\section{As imagens medievais}

É possível uma história da cultura visual medieval? Para respondermos a esse questionamento, temos que lembrar que o debate acerca da imagem no Medievo, no contexto da história da arte, não é novo, muito menos esgotado. Os "artistas", as pessoas que são dedicadas a um ofício específico voltado à produção de objetos contemplativos, da maneira como conhecemos no mundo moderno, não existiam no medieval, pelo menos até o século XIII, cabendo a esses profissionais a expressão mais comum de artífices (CASTELNUOVO, 1989, p. 146). No scriptorium medieval, por exemplo, o trabalho do copista era considerado mais importante e com mais prestígio social que do pintor de miniaturas, pois as assinaturas e as imagens dos scriptor são mais abundantes que as dos desenhistas, ao menos em glosas românicas (CASTELNUOVO, 1989, p. 151). Quanto às imagens medievais, Jérôme Baschet chama a atenção para uma interessante relação entre arte e suporte: não há na Idade Média imagem que seja ao mesmo tempo um objeto ou, “... pelo menos, que não esteja apenso a um objeto, a qual constitui a decoração e que ela acompanhe o uso - um manuscrito, um altar, um relicário, de fato a casa cultual em si mesma" (BASCHET, 
2008, p. 33). A noção de imagem-objeto sugere que a imagem medieval está inseparável da materialidade de seu suporte, mas também de sua existência enquanto objeto (BASCHET, 2008, p. 33). O uso do termo imagem, portanto, opõe-se ao uso da palavra arte, obra de arte ou artista, pois, estas noções "não existiam de forma autônoma na Idade Média" (BASCHET, 1996, p. 10). O historiador, cujo propósito é analisar imagines medievais, deve considerar toda a estrutura em que está fixada a pintura, suas relações simbólicas com os textos, e o lugar que ocupa na superfície do manuscrito.

Quando tomamos as letras historiadas, caso do manuscrito w.133, observamos que o uso ornado da letra possui uma funcionalidade que vai além do campo estético, mesmo considerando que a beleza também cumpria os papéis funcionais da imagem. Ao estilizar a letra capitular, o miniaturista conecta o desenho ao texto, dando a ela a dupla característica funcional e "artística”, ou imagética: “... a imagem não é autônoma em relação ao texto; ela se reporta, ao revés, àquilo que faz sua materialidade, a letra" (BASCHET, 1996, p. 11). A letra ornada é uma imagem-objeto, nas palavras de Baschet, porque a imagem está diretamente vinculada ao objeto e suas funcionalidades. A letra capitular estilizada marca o início de um parágrafo, separando e organizando o texto, ao mesmo tempo em que é produtora de discursos, ao narrar, e mesmo ressignificar, elementos contidos no texto "principal". Não à toa, a capitular toma um espaço decisivo no manuscrito, dialogando com outros objetos, servindo como elemento decorativo e contemplativo.

Sobre os lugares que as letras ornadas ocupam, além de outros registros imagéticos, Schmitt considera que as imagens não devem assinalar a ilustração de um texto, isto é, cada uma dessas formas de fixação do pensamento, imagem e língua designam aspectos discursivos totalmente diferentes: “... exprimem e produzem ao mesmo tempo uma classificação de valores, hierarquias, opções ideológicas" (SCHMITT, 2007, p. 34). Uma letra capitular, à primeira vista, pode significar para o historiador desatento, uma expressão figurativa cuja principal função é exemplificar o texto ao qual ela está diretamente relacionada. Lembremos que as letras ornadas constituem um tipo de imagem que é ao mesmo tempo figurativa e textual. Não devemos analisar as capitulares de maneira radicalmente separada da estrutura da obra escrita, mas podemos apreender elementos discursivos presentes na iconografia que demonstram possibilidades interpretativas para além do texto. Segundo Schmitt, as 
iniciais iluminadas são capazes de jogar “... com o tamanho e a atitude dos personagens (sentados, de pé), a escolha e a saturação das cores e de sua vestimenta e, sobretudo, com a posição adiante ou detrás que essas figuras decoram...” (SCHMITT, 2007, p. 38). Essa é uma operação complexa, pois as imagens "revelam" componentes que não estão presentes no texto, como os lugares sociais hierarquizados dos personagens desenhados, ou mesmo gestos que indicam contradições com a narrativa escrita.

Em relação às miniaturas historiadas, sabe-se que as sequências iconográficas estruturam a narrativa em si, garantindo um alto grau de autonomia à imagem em relação ao texto escrito. Com isso, o miniaturista sequencia os objetos existentes nos quadros, repetindo o ambiente, cores, personagens, vestuário, etc., e forma, assim, uma composição linear, caso do manuscrito 262. Uma reflexão que podemos fazer é considerar que há independência da iconografia em relação ao texto, tornando a cultura visual um elemento complexo capaz de produzir suas próprias significações. Para Daniel Russo, entre os anos de 1960 e 1980, ainda prevalecia a opinião de que a imagem estava subordinada ao texto em manuscritos medievais, seja nas reflexões semióticas, das quais elas contêm signos implícitos, estruturados em si, ou nas representações culturais, que as colocaram com um forte conteúdo construído a partir do exterior: "Em suma, isso marca um excesso de semiotização que só considera o visível enquanto ele é legível” (RUSSO, 2011, p. 40). Cabe hoje compreendermos a miniatura historiada, como outras imagens medievais, como discursos capazes de conceber vida própria, construindo contextos históricos complexos.

\section{O manuscrito w.133}

Embora não seja propriamente o objeto deste trabalho, chamo a atenção aqui para uma interessante colocação de Michael Camille acerca do uso do plano da página pelos glosadores medievais. Até o século XII, a palavra escrita estava no plano de organização do manuscrito como uma sugestão para a fala em voz alta do leitor. Isto porque o "... sentido da escrita dos monges era chamado meditatio, no qual cada palavra era mastigada e digerida para memorização, sendo proferida em voz alta" (CAMILLE, 2012, p. 18). No fim do século XII, com o crescimento de formas de instrução tanto devocional quanto universitária, novos métodos de organização da página, o chamado 
ordinatio do texto, substituiu o monástico meditatio. As palavras deixaram de ser vistas como desenhos a serem falados e tornaram-se uma “... materialidade física da escrita como um sistema de signos visuais que estava em evidência" (CAMILLE, 2012, p. 20). Com isso, as letras se tornaram mais curtas, o que possibilitou que as iniciais historiadas, as capitulares ornadas, dos manuscritos góticos fossem melhor organizadas no espaço esquadrinhado do suporte. Esse processo deu lugar, por exemplo, ao afastamento em direção à margem do manuscrito para as imagens discrepantes, e divertidas, em relação ao conjunto do documento (CAMILLE, 2012, p. 20).

Com essa hipótese a respeito da organização do texto, as iniciais historiadas ganham uma maior dedicação estilística. Não que não houvesse antes do século XII capitulares detalhadas, mas elas se tornaram mais usuais nos manuscritos góticos. Assim, podemos inferir que a imagem que iremos analisar, que é uma capitular correspondente à letra $Q$ (inicial de Quidam maleficiis inpeditus...), é capaz de produzir efeitos discursivos que amplificam as vozes da narrativa textual do decreto de Graciano.

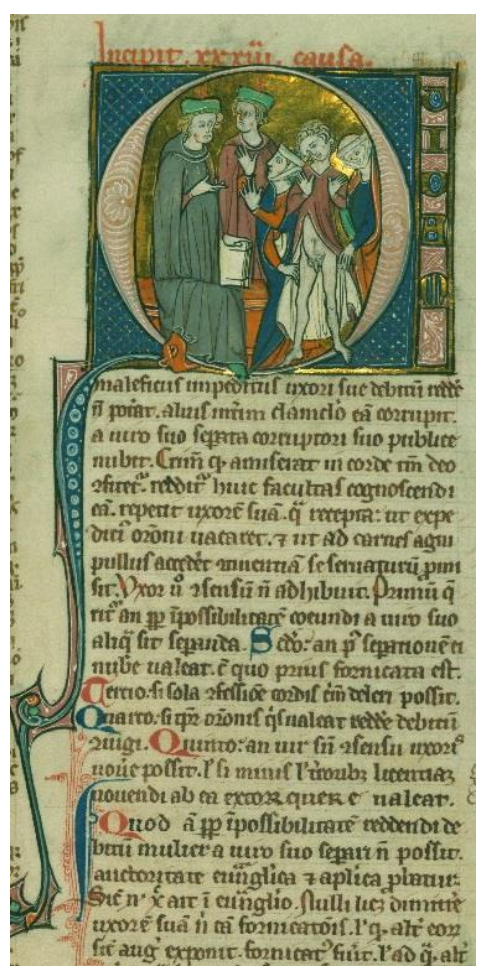

Imagem 1: Decretum de Graciano, ms w.133, f. 277r, Walters Art Museum, Baltimore, EUA 
A causa 33 começa com a seguinte sentença: "Um homem foi impedido por um feitiço de pagar a dívida a sua esposa" (GRACIANO, 1994, s/p). O termo que corresponde à impotência derivada de feitiço é chamado de maleficium, segundo Catherine Rider: "A maioria dos escritores medievais do século XII em diante tinha um conceito muito claro do fenômeno que denominei de 'impotência magicamente causada" (RIDER, 2006, p. 7). Este conceito (maleficium) foi formulado por advogados canônicos, em seguida por teólogos, sendo uma palavra que poderia significar qualquer tipo de crime, “... que nem sempre denotava a causa intencional do dano, mas por meios misteriosos" (RIDER, 2006, p. 7). A ideia de que a impotência implicaria a anulação de um casamento não era novidade para Graciano. Ainda no século IX, Hincmar, arcebispo de Reims entre 845 e 882 , escreveu o tratado De Divortio, em que buscou argumentar os motivos pelos quais o rei Lotário deveria permanecer casado com sua esposa Theutberga. Lotário pretendia o divórcio porque queria se casar com sua concubina, Waldrada, alegando que estava impotente devido a um feitiço. Mas Theutberga resistiu com o apoio do Papa Nicolau I. No século XI, o canonista Ivo de Chartres escreveu o Decretum, uma coleção de mais de três mil páginas que reunia cartas papais, atas de concílios da Igreja, penitenciais e textos dos Pais da Igreja (RIDER, 2006, p. 56). Este volumoso trabalho recebeu uma versão síntese, chamada de Panormia, a qual incluía comentários sobre anulação do casamento baseado na impotência causada por feitiçaria Si per sortiarias (RIDER, 2006, p. 57). Se observarmos com atenção os personagens dispostos na miniatura, teremos alguns indícios sobre maleficium. Nota-se que duas mulheres à direita desnudam um homem, exibindo seu pênis flácido. No canto esquerdo, há dois homens. Aparentemente o que está sentado e segurando um livro parece ser um bispo, enquanto o que está no plano detrás sugere também ser um clérigo. O quinto elemento que participa da cena é a cabeça de uma raposa aos pés do bispo, que o olha fixamente. Seria essa raposa, cujo olhar espelha o da esposa requisitante, a manifestação do maleficium?

É o conjunto dos personagens e suas ações dialógicas por meio de uma gestualidade que busco complexificar ao comparar com a redação do Decretum. Há quatro personagens cujas mãos marcam diferentes formas de diálogos por meio do simbolismo dos gestos. Quando olhamos o homem seminu, com a cabeça baixa, e as mãos abertas voltadas para fora, observamos um sinal de resignação. Segundo François 
Garnier, a mão aberta, com a palma voltada ao exterior, significa, de acordo com o contexto, disponibilidade, aceitação ou adesão (GARNIER, 1982, p. 174). Já os outros três personagens à esquerda (a mulher, o bispo e o outro clérigo) parecem dialogar entre si, visto que estão voltados uns para os outros através do olhar. Essa conversação também envolve as mãos. A discussão é marcada pelas mãos abertas, significando que há um processo de negociação e convencimento em curso. A posição do bispo é a mais proeminente, pois a mão direita aberta com a palma voltada para cima, enquanto a esquerda se apoia em um livro, demonstra hierarquia e superioridade na tomada de decisões que se baseiam nas escrituras, como se o desfecho dependesse daquilo que diz o livro. A mulher argumenta, e o bispo analisa o teor da alegação.

O outro elemento que desperta curiosidade é um animal que identifiquei como sendo uma raposa (volpi), aos pés do bispo. Sua inserção feita pelo miniaturista é fundamental para analisar os discursos, por exemplo, de gênero. Nota-se que os olhares da mulher e da raposa estão simetricamente direcionados ao bispo. Uma das intenções é assimilar mulher e animal, como se a imagem do animal espelhasse o olhar da esposa, igualando-os. Para o chamado bestiário latino, a raposa é descrita como “... um animal astuto, bastante fraudulento e engenhoso". ${ }^{3}$ Essa descrição é fundamental para entendermos a construção discursiva da imagem, pois a raposa é capaz de enganar de maneira habilidosa, assim como a mulher que quer anular o casamento, mas já possui um amante com quem quer constituir novo matrimônio. Por isso, há um esforço por parte do miniaturista em correlacionar a mulher que quer o divórcio e a raposa como um animal enganador.

\section{O manuscrito 262}

Os elementos visuais encontrados no manuscrito w.133 não podem ser emparelhados simetricamente com os do Fitzwilliam Museum. Com propostas diferentes, mas tratando do mesmo tema, a causa 33, os miniaturistas privilegiaram traços que capturam trechos do Decretum, cada qual a sua maneira. Enquanto o manuscrito w.133 condensa a discussão sobre o divórcio em uma única capitular, o 262 utiliza a miniatura historiada. Com esse recurso visual, as divisões em quadrinhos narram por etapa, sequenciando de maneira didática o Decretum. 


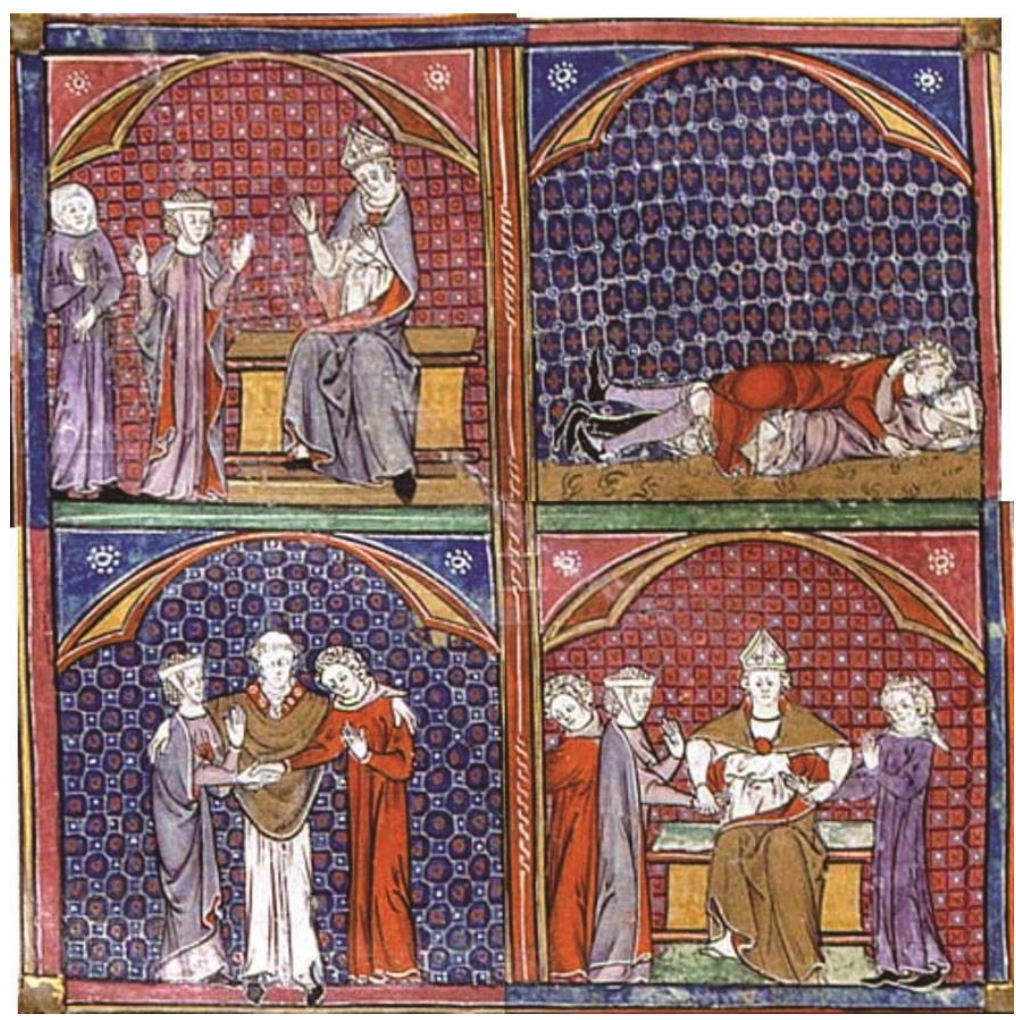

Imagem 2: Decretum de Graciano, ms 262, fólio 86v, Fitzwilliam Museum, Cambridge, Inglaterra

Percebe-se que a história narrada em quatro quadros é relativamente confusa. Começando com três personagens, ao que parece há uma mulher ao centro, gesticulando com uma das mãos apontando para um personagem masculino à esquerda. A outra mão aparece com a palma aberta em direção a um clérigo. A ideia fixada na iconografia sugere que se trata da esposa imputando ao marido algum delito. Pelos gestos manuais dela, parece que a esposa argumenta a seu favor, contra o esposo. Sabemos pelo texto da causa 33 que não se trata de um crime, mas da impotência do marido que não conseguiu consumar o casamento. Mesmo que as imagens não possuam legendas, imaginamos que a miniatura narrada começa, então, com a denúncia e o pedido de anulação da união matrimonial.

Para Brundage, nesta cópia do Decretum, de Graciano, o miniaturista inverteu a ordem dos fatos (BRUNDAGE, 1987, p. 325). Se seguirmos a história narrada por Graciano, a queixa levada à Igreja ocorre depois que a esposa descobre a impotência do 
marido. Sendo assim, é mais provável que o segundo quadrinho, na verdade, seja o primeiro, pois apenas depois do ato sexual é que se percebe a ineficácia do homem. Além disso, há outro problema: pode-se atestar uma descontinuidade nas cores do desenho. Uma forma de marcar o ritmo às imagens é a manutenção das roupas nos desenhos seguintes. Vê-se que na primeira imagem há um homem com uma túnica diferente da vermelha que aparece na sequência. Esse detalhe faz pensar que, na verdade, trata-se do amante da esposa que a acompanhou até o bispo. Aparentemente, este mesmo homem ressurge no último quadro. É uma hipótese.

O segundo quadro retrata uma relação sexual cujo homem está por cima da mulher. Para reforçar a posição do marido, o miniaturista (ou o pintor, porque as etapas de desenho e pintura podiam ser separadas) escolheu uma cor bem marcante, o vermelho. A mulher está com o vestido um pouco levantado, exibindo parte da perna esquerda. Há inclusive um gesto singelo das mãos que entrelaçam o companheiro de maneira afetuosa. Imagens de relações sexuais não são incomuns nas miniaturas medievais. As Cantigas de Santa Maria, compilação de poemas e iconografias coordenadas por Alfonso X no século XIII, em Castela, apresentam em seu conjunto algumas imagens em que parceiros estão em posições sexuais. Para marcar a continuidade das ações, o miniaturista manteve o ambiente de coloração azul com arcos em vermelho e amarelo na terceira cena. Esse recurso, assim como do vestuário, é comum, e serve para que o expectador perceba o movimento seguinte dos personagens. No terceiro quadrinho, o casal, ao que parece, recebe a visita de um clérigo em sua residência e os três entram em um acordo de separação. A mulher gesticula com a palma da mão esquerda voltada para o marido, enquanto este recebe o gesto, sinalizando para si com a palma da mão aberta. A cabeça do marido, levemente abaixada, com os olhos apontados para o chão, também marcam sua resignação (GARNIER, 1982, p. 141). O clérigo que abraça a ambos, no terceiro quadro, não parece ser o mesmo da primeira e da última cena, pois nestas o sacerdote surge com uma mitra, que é uma insígnia episcopal.

$\mathrm{Na}$ última cena, percebemos que a miniatura busca representar a ação eclesiástica para mediar o divórcio do casal e permitir à mulher novo matrimônio com outro homem, aparentemente, seu antigo amante. O primeiro marido sai em direção à saída do espaço onde um novo acordo se estabelece, ainda com a cabeça levemente 
abaixada. O bispo está no centro do quadro, sentado, com atmosfera proeminente, segurando as mãos do novo casal. Os gestos dos noivos demonstram a aceitação da nova condição matrimonial: ambos com a palma da mão esquerda voltada para o outro. A mão direita dos cônjuges está sendo conduzida pelo bispo.

\section{Algumas conclusões entre texto e imagens no Decretum de Graciano}

O contexto em que se produziu o Decretum de Graciano poderia ser associado, de maneira dialética e em níveis nem sempre coerentes, à chamada Reforma da Igreja, entre os séculos XI e XIII, e mais especificamente, nesse mesmo contexto, ao Segundo Concílio de Latrão, realizado por Inocêncio II em abril de 1139. Embora esse longo e complexo caso de reforma papal ainda seja chamado de "reforma gregoriana", entendemos que se tratou de heterogeneidades e esforços de sucessivos papas, indo além de Gregório VII, seu principal propagador (PAUL, 1988, p. 209). Como afirma André Vauchez, esse conjunto de ações da Igreja visava a libertas, ou seja, a independência em relação ao imperador e o direito inconteste de julgar a sociedade cristã (VAUCHEZ, 1995, p. 58). Gregório VII, com seu pontificado, entre 1073 e 1085, apelou para reforma como uma maneira de "salvar o mundo", colocando os dirigentes eclesiásticos à frente dessa missão, exaltando o sacerdócio.

O Decretum passaria a fazer parte de uma das primeiras tentativas da Igreja em controlar normativamente as sociedades entendida como pertencentes à cristandade, impondo um código jurídico da Igreja ao conjunto de fiéis. Por isso, Graciano buscou construir um texto que fosse dirigido tanto aos clérigos quanto aos leigos. A extensão de causas do Decretum aponta para a dupla missão da ordem normativa: dessacralizar o Império e a investidura leiga. $\mathrm{Na}$ tradição desde o período merovíngio, o príncipe designava o bispo e lhe dava a investidura. Assim, a eleição do titular de um cargo eclesiástico e quais eram suas atribuições se tornou um dos problemas centrais com que a Reforma se preocupou e, como lembra Paul, a linha de reflexão da Igreja era de que a alma era superior ao corpo e, em consequência, em uma sociedade o espiritual não poderia ser subordinado ao temporal (PAUL, 1988, p. 234). Tratava-se de um jogo de poder em que os papeis desempenhados pelos clérigos estavam limitados pelas constantes intervenções reais. E ainda Grossi acrescenta: a Igreja não tinha um corpus 
documental de caráter jurídico, nem mesmo o código Justiniano, uniforme e organizado. Graciano surgiu como alguém que, de forma ainda rudimentar, sistematizou uma plataforma coerente capaz de atrair os interesses clericais para construção de um direito canônico em consonância com a reforma (GROSSI, 2014, p. 251).

Se o Decretum, neste ponto, parece pautar a querela das investiduras e suas implicações nas hierarquias eclesiais, também precisamos olhar outras questões que, aparentemente, estão margeadas nas discussões políticas envolvendo os textos normativos medievais. Para isso, propomos que o gênero possa entrar no debate para aprofundar nossas análises historiográficas, inter-relacionando o código jurídico às relações de gênero nas disputas e discursos de poder. Ressalto alguns pontos acerca das estratégias de que o miniaturista lançou mão para que a mulher pudesse ser vista como alguém que consegue enganar o marido, anular seu casamento e se afiliar ao amante.

Quando observamos o manuscrito w.133, a nudez é um elemento flagrante na miniatura aos olhos dos que a observam, pois o homem nu está à frente de três personagens, no primeiro plano da cena. Com as mãos abertas voltadas para fora, o homem demonstra resignação diante de sua situação vulnerável aos olhos vigilantes dos demais personagens. A exposição do nu demonstra o quanto o corpo é referendado como objeto de curiosidade e julgamento. Fato é que no texto jurídico não há menção alguma à presente cena, isto é, não há nenhum trecho em que se diga que o marido foi exposto dessa maneira às autoridades eclesiásticas. Mas ainda há um elemento curioso: são duas mulheres no quadro. Uma delas, a que abre a capa do homem e mais próxima aos clérigos, aparentemente, é a esposa exigindo a separação por ausência de intercurso. Entretanto, e a segunda mulher no canto direito? Talvez seja uma testemunha. Brundage levanta essa questão ao sublinhar as dificuldades de se provar acordos estabelecidos de forma oral, assim como há problemas iguais para as relações sexuais (BRUNDAGE, 1987, p. 237). Acordos frequentemente possuem testemunhas, relações sexuais não. O papel, portanto, da outra mulher seria atestar a veracidade da narrativa da esposa, colaborando com o desnudamento do marido, evidenciando o pênis márcido a todos.

Não há referências diretas à presença de testemunhas que sejam obrigatoriamente mulheres na Causa 33. Citando papa Nicolau (Causa 33, questio 2, parte 2, capítulo 4), Graciano aponta que, caso o marido deixe sua esposa, deve-se providenciar um lugar adequado, livre de pressões externas, para que se possa ouvir as 
partes. Neste caso, eles poderiam constituir testemunhas e ficar com parentes consanguíneos (GRACIANO, 1994, s/p). Em relação à letra capitular, a mulher que aparece no canto direito não apenas parece ser uma personagem atestadora da impotência, como também participativa da história para tentar anular o casamento. Vemos que a possível testemunha colabora efetivamente com a questão, intervindo para ajudar a esposa ao exibir a condição fálica do marido. O mesmo não ocorre nas iconografias historiadas, pois não há a presença de outras pessoas externas ao litígio.

Mas a figura de poder que está nas duas imagens certamente é o bispo. Esse personagem tem proeminência nos diálogos por meio dos gestos manuais ponderados, concentrando em si as decisões fundamentais da disputa pela separação. No entanto, a causa 33 não menciona explicitamente os detalhes sobre quais funções os clérigos teriam como juízes ou mesmo mediadores de processos matrimoniais. Observando as duas imagens, sustentamos que o miniaturista quis situar sacerdotes no papel decisório por conta da maneira em que foram colocados na iconografia. Verificamos que tanto na capitular quanto na história miniada há um clérigo sentado cuja posição em destaque entendemos ser a de um bispo em sua cátedra, podendo também estar relacionado ao espaço da sé episcopal. Essa peça mobiliária tem a função de evidenciar que um dos personagens ocupa um espaço distinto aos demais.

Na causa 33, as referências mais diretas ao bispo como uma espécie de juiz ocorrem quando Graciano se esforça para responder à quinta questio: um marido pode adotar o celibato sem o consentimento de sua esposa, ou se ele poderia conseguir a "autorização" da esposa por meio da violência e da coerção, ou seja, o marido pode forçar a mulher a aceitar sua impotência sexual? Analisando diversos argumentos sobre punição à mulher por descumprimento dos acordos matrimoniais, Graciano menciona Ambrósio, arcebispo de Mediolano no século IV, em um comentário sobre o Antigo Testamento: "Uma esposa não tem poder próprio, mas é submetida ao domínio do marido em tudo" (GRACIANO, 1994, s/p). A lógica argumentativa é de que o homem é a cabeça da mulher e ela não poderia fazer nenhum voto de abstinência ou conversão religiosa sem o consentimento do marido.

Assim, o escriba desenvolve seus discursos se orientando tanto pela tradição canônica quanto pelos textos bíblicos, em especial o Antigo Testamento. Como sugere Brundage, Graciano acreditava que a castidade, vista como uma forma de abstinência 
sexual, de uma das partes poderia descumprir o acordo fundamental do casamento, que era o intercurso, o ato sexual em si (BRUNDAGE, 1987, p. 239). Não é surpreendente que a inserção da autoridade episcopal nas imagens tenha a incumbência de representar a intermediação entre um casal em situação litigiosa, em que a mulher acusa seu marido de não cumprir o intercurso, ou seja, de romper um contrato. Mas, e se a mulher não aceitar a decisão do marido em não praticar sexo? A quem ela recorre? Daí que aparece a figura do bispo no Decretum. Citando o texto da Primeira Epístola aos Coríntios, Graciano indica que a mulher deve sempre cobrir a cabeça, visto que é um símbolo de sujeição e que a queda (expulsão) do paraíso começou com ela e “... em respeito ao bispo, permita que ela não tenha a cabeça descoberta na igreja, mas coberta por um véu" (GRACIANO, 1994, s/p). ${ }^{5}$ A mulher é apresentada na questio 5 como alguém que deve respeito às figuras eclesiásticas, em especial na presença do bispo cuja missão é representar Cristo: "Não deixe que ela tenha o poder de falar, porque o bispo representa a pessoa de Cristo. Como ela seria diante de Cristo, o juiz, então seja diante do bispo, porque ele é o vigário do Senhor" (GRACIANO, 1994, s/p). ${ }^{6}$ Nesse fragmento da Causa 33, o bispo surge como alguém que submete a esposa a uma arbitragem, na medida em que ele é legitimado como alguém a serviço não apenas da cristandade, mas da própria pessoa do Cristo.

O manuscrito 262 demonstra uma narrativa aproximada com a capitular, pois a proeminência do bispo nas imagens é flagrante. Dos quatro quadros, em dois a autoridade clerical está em destaque, visto que ele sempre é a figura dominante, ocupando o espaço pelo tamanho que o miniaturista deu a sua estatura. Além disso, nos quadros um e quatro, o bispo está mediando um distrato, provavelmente de separação das partes. Em um momento ele estabelece o fim do casamento e no outro o novo enlace da mulher e do seu amante.

Graciano produziu uma compilação complexa, edificada a partir de múltiplas fontes. Não por caso, seu Decretum ocupou um lugar de notoriedade na história eclesiástica. As miniaturas dos manuscritos não poderiam ter a função de agrupar as discussões contidas nos textos. Ao contrário, elas são capazes de elaborar novas narrativas, por vezes contraditórias e avessas ao corpus textual. Nos manuscritos w.133 e 262, os miniaturistas buscaram selecionar fragmentos do Decretum, provavelmente considerando a problemática da história: o fim de um casamento por impotência sexual. 
Cada qual tratou o homem e a mulher como partes desiguais de uma relação de gênero. No w.133 o homem tem o corpo exposto, vítima de feitiçaria, porém, ao mesmo tempo, a cabeça de uma raposa sugere que a mulher tramava a separação por meio de uma maquinação. No manuscrito 262, o homem é apresentado como um sujeito resignado, que aceita o fim do contrato, culminado com um novo esponsal da mulher recémseparada.

O gênero se constitui de maneira desigual, complexa e instável nas relações sociais. Isso porque, se o marido parece conformado com sua impotência e resignação, o bispo, outro homem da narrativa, assume o protagonismo nas relações de poder, decidindo sobre os papeis que as partes assumem ao romper o contrato matrimonial. Enquanto isso, a esposa buscou romper esses papeis tornando pública a impotência do marido. Ao casar-se novamente, ela reivindicou juridicamente um novo status para não ter que retornar para seu primeiro compromisso. O litígio foi iminente quando o marido recuperou a virilidade, mas quis o celibato como decisão pessoal e vivência espiritual. A esposa, então, não aceita a condição de casada sem que haja prática sexual. Entretanto, as possíveis maneiras de se exercer a justiça ainda, segundo o Decretum, concentram-se nas tradições cristãs.

\section{Bibliografia}

BASCHET, Jérôme. Introdução: a imagem-objeto. In: SCHMITT, Jean-Claude et BASCHET, Jérôme. L'image. Fonctions et usages des images dans l'Occident médiéval. Paris: Le Léopard d'Or, 1996. p. 7-26. (tradução: Maria Cristina C. L. Pereira)

BASCHET, Jérôme. L'iconographie médiévale. Paris: Gallimard, 2008.

BRUNDAGE, James A. Law, Sex, and Christian Society in Medieval Europe. Chicago, Londres: The University Chicago Press, 1987.

CAMILLE, Michael. The Image on the Edge - the margins of medieval art. Londres: Reaktionbooks, 2012.

GARNIER, François. Le Langage de l'Image - signification et symbolique. Paris: Le Léopard d'Or, 1982.

GARNIER, François. Le Langage de l'Image au Moyen Âge II - gramaire des gestes. Paris: Le Léopard d'Or, 1988.

GROSSI, Paolo. A Ordem Jurídica Medieval. São Paulo: Martins Fontes, 2014. 
MIRANDA VICENTE, Francisco. Manuscritos del decreto de Graciano en la biblioteca catedral de Toledo. Revista Española de Derecho Canónico, $\mathrm{n}^{\mathrm{0}}$ 20, vol. 7, 1952, p. 391-415.

NOONAN, Jr., John T. Marriage Canons from the Decretum of Gratian. Disponível

https://classesv2.yale.edu/access/content/user/haw6/Law/marry.htm\#C33. Acesso em 4 de fevereiro de 2019.

PAUL, Jacques. La Iglesia y la Cultura en Occidente (siglos IX - XII) - La santificación del orden temporal y espiritual. Barcelona: Editorial Labor, 1988. 2 volumes.

PAUL, Jacques. La Iglesia y la Cultura en Occidente (siglos IX - XII) $-E l$ despertar evangélico y las mentalidades religiosas. Barcelona: Editorial Labor, 1988. 2 volumes.

PENNINGTON, Kenneth. The Biography of Gratian, the Father of Canon Law. Villanova Law Review, $\mathrm{n}^{\mathrm{o}}$ 59, 2014, p. 679-706.

RIDER, Catherine. Magic and Impotence in the Middle Ages. Nova York: Oxford University Press, 2006.

RUSSO, Daniel. O conceito de imagem-presença na arte da Idade Média. Revista de História, São Paulo, n. 165, p. 37-72, 2011.

SCHMITT Jean-Claude. O Corpo das Imagens - ensaios sobre cultura visual na Idade Média. Bauru: Edusc, 2007.

SCOTT, Joan Wallach. Gênero - uma categoria útil de análise histórica. Educação \& Realidade. Porto Alegre, v. 20, n. 2, p. 71-99, jul./dez. 1995.

VAUCHEZ, André. A Espiritualidade na Idade Média Ocidental. Rio de Janeiro: JZE, 1995.

VIEJO-XIMÉNEZIUS, José Miguel. La composición del decreto de Graciano canonicum, Ius Canonicum, n. ${ }^{\circ}$ 90, 2005, p. 431-485.

WINROTH, Anders. Recent Work On The Making Of Gratian's Decretum. Twelfth International Congress of Medieval Canon Law, Washington, 5 de agosto de 2004, Atas... Cidade do Vaticano: Biblioteca Apostólica Vaticana, 2008. p. 1-29.

WINROTH, Anders. The Making of Gratian's Decretum. Cambridge: Cambridge University Press, 2000.

\footnotetext{
${ }^{1}$ Os manuscritos que estão no centro desse debate são: ms (Aa) 23 e 43, Admont, , Stiftsbibliothek, Áustria; ms (Bc) 78, Barcelona, Arxiu de la Corona d'Aragó, Santa Maria de Ripoll, Itália; ms (Fd) A 1402, Florença, Biblioteca Nazionale Centrale, Conventi Soppressi, Itália; ms (P) lat. 1761, Paris, Bibliothèque Nationale de France, França; ms (Pfr) lat. 3884 I-II, f.1 (fragmento), Paris, Bibliothèque Nationale de France, França; ms. (Sg) 673, Sankt Gallen, Stiftsbibliothek, Suiça.

2 O manuscrito w.133 e os detalhes da obra estão disponíveis em: http://www.thedigitalwalters.org/Data/WaltersManuscripts/html/W133/description.html. Já o ms 262 pode ser consultado em https://www.fitzmuseum.cam.ac.uk/pharos/collection_pages/middle_pages/Ms.262/TXT_SEMs.262.html. Acessado em 10 de janeiro de 2019.
} 


\footnotetext{
${ }^{3} \mathrm{O}$ termo Fisiólogo foi-se transformando naquilo que conhecemos como bestiários medievais. A partir do século XII, há, gradativamente, a incorporação do De Animalibus, o Livro XII das Etimologias de Isidoro de Sevilha. Isso ocorre devido à forma de organização dos capítulos, os nomes e características morais atribuídas aos animais. Ver: http://kidslink.bo.cnr.it/irrsaeer/bestiario/beslat/vulpis.html. Acessado em 23 de fevereiro de 2019.

4 "Nulla est mulieris potestas, sed in omnibus viri domínio subsit." (Causa 33, questio 5, capítulo 18).

5 "Out of respect for the bishop, let her not have her head uncovered in church, but covered by a veil." (Causa 33, questio 4, c. 19).

6 "As she would be before Christ the Judge, so let her be before the bishop, because he is the Lord's vicar." (Causa 33, questio 4, c. 19).
} 